\title{
Polymorphism in the Plasmodium vivax msp $3 \alpha$ gene in field samples from Tierralta, Colombia
}

\author{
Fabio Aníbal Cristiano, Manuel Alberto Pérez ${ }^{1}$ Rubén Santiago Nicholls ${ }^{1}$, Angela Patricia Guerra/ ${ }^{+}$ \\ Grupo de Bioquímica y Biología Celular, ${ }^{1}$ Grupo de Parasitología, Instituto Nacional de Salud, Av. Calle 26 N 51-20, Bogotá, DC, Colombia
}

We evaluated the Plasmodium vivax polymorphism by studying the Pvmsp-3a gene's polymorphic region by PCR-RFLP in 55 samples from patients living in Tierralta, Colombia. Three different sizes of the Pvmsp-3a gene were found, type $A$ (1,900 bp), type B (1,500 bp) and type C (1,100 bp); most of the samples were type $A(96.4 \%)$. The Pvmsp-3a gene exhibited high polymorphism. Seven restriction patterns were found when using Alu I, and nine were found with Hha I; 12 different alleles were obtained when these patterns were combined. The findings suggest that this gene could be used in Colombia as a molecular epidemiologic marker for genotyping P. vivax.

Key words: Plasmodium vivax - Colombia - genetic polymorphism

It is well known that vivax malaria is not lethal but does cause great morbidity; however, mortality caused by this species in South America has alarmingly been described during the last few years (Rodríguez-Morales et al. 2008), as well as the emergence of chloroquineresistant parasites (de Santana Filho et al. 2007). Analyzing parasite population structure is fundamental in understanding the role of genetic diversity in malarial transmission. Knowledge about the magnitude of genetic polymorphism within the parasite population is an important element in developing strategies and effective means of controlling malaria (Cui et al. 2003a). Several polymorphic genes, such as the gene encoding the Duffy binding protein region II, the circumsporozoite protein Pvcsp and merozoite surface proteins Pvmsp (de Souza-Neiras et al. 2007), have been used for evaluating the genetic diversity of Plasmodium vivax. However, new and more proper population genetic markers have been recently developed to investigate the population structure of this species, such as microsatellite markers (Imwong et al. 2006) and single-nucleotide polymorphisms (Feng et al. 2003).

Even though $P$. vivax is responsible for the majority of malaria cases in Colombia (65\%), very few studies have been done concerning the genetic diversity of the natural populations. González's work using the Pvcsp gene showed that the allele types VK210 and VK247 were present with a predominance of the VK247 type (González et al. 2001). Mancilla et al. (1994) analyzed the $m s p 1$ gene, finding two allele forms that were analo-

Financial support: Fondo de Investigaciones en Salud, Ministerio de la Protección Social-Colciencias (proj. 2104-04-16338), Instituto Nacional de Salud, Secretaría Departamental de Desarrollo de la Salud de Córdoba

+ Corresponding author: aguerra@ins.gov.co

Received 30 April 2008

Accepted 21 July 2008 gous to those found in the P. vivax Belem and Salvador I strains. More recent studies reported a third allele type (Maestre et al. 2004), and a high polymorphism in the Pvmsp 1 gene from wild isolates was found by Gutierrez et al. (2000), reflected in five identified sequence types.

Several works have found a greater variety of parasites when analysing the Pvmsp3a gene as compared to other molecular markers. This gene has a highly polymorphic central domain flanked by conserved regions. This type of domain presents size and sequence polymorphism and may be analyzed by using a simple PCR/RFLP protocol. The aim of this study was to evaluate the usefulness of the Pvmsp $3 \alpha$ molecular marker in Colombian field samples for the first time and to identify the parasite's allele types circulating in the locality of Tierralta.

\section{PATIENTS, MATERIALS AND METHODS}

Study areas - The study was carried out in Tierralta, located in the department of Córdoba, in Northwestern Colombia. Its average temperature is $27^{\circ} \mathrm{C}$, its altitude is $5 \mathrm{~m}$ a.s.l., and it lies within an ecological region of tropical dry forest. Tierralta contributed $13.4 \%(13,940$ cases) of the malaria cases reported in Colombia in 2005 (INS 2005), 8,790 of which were from $P$. vivax. Tierralta's zone is considered a high transmission one with an annual parasite index (API) greater than 10 (API: 304/1.000; annual $P$. vivax index: 192/1.000; annual $P$. falciparum index: 106/1.000).

Sample collection - After obtaining informed signed consent, 56 blood samples were collected from $P$. vivaxinfected patients between May and July of 2006, within the context of an in vivo efficacy study of chloroquine for the treatment of vivax malaria. A blood sample was collected on $1 \mathrm{~cm}$ diameter filter-paper circles from all the patients included in the study before treatment was started (day 0). All of the patients presented an adequate clinical response to treatment after 28 days of followup; two patients (15 and 30) who had previously been included in the study returned on days 42 and 51 as they presented symptoms, entering the study for the 2 nd time and were considered as new patients (Pérez et al. 2008). 
PCR amplification of the Pvmsp $3 \alpha$ gene - Extraction of parasite DNA was done according to Guerra et al. (2006). Polymorphism in the Pvmsp $3 \alpha$ gene was analyzed using the PCR-RFLP protocol as described by Bruce et al. (1999). The PCR mixture (outer PCR) was prepared with $\mathrm{P} 1$ and $\mathrm{P} 2$ primers, and the nested PCR mixture was prepared with primers $\mathrm{N} 1$ and N2. These products were resolved on $1 \%$ agarose gel and the sizes were determined by using the $1 \mathrm{~Kb}$ ladder. The Salvador I strain was included as a positive control; all of the samples were analyzed in duplicate for confirmation of the reproducibility of the results.

$P C R$-RFLP-Tworestriction enzymes (Alu I and $H h a \mathrm{I}$ ) were used for the molecular genotyping. Each mixture was incubated at $37^{\circ} \mathrm{C}$ for $4 \mathrm{~h}$, and the DNA fragments were resolved on $2 \%$ agarose gels, stained with $1 \mu \mathrm{g} /$ $\mathrm{ml}$ ethidium bromide solution and visualized under UV light. The results were recorded and analyzed on a Gel Doc XR image analyzer using Quantity One software. Restriction product size was determined by using a $100 \mathrm{bp}$ molecular weight marker as reference and the Salvador I strain for which theoretical 975, 465, 405 and $63 \mathrm{bp}$ cuts are obtained with $H h a \mathrm{I}$, and 537, 258, 189, 172, 156, 153, 150, 146, 69, 51 and 27 bp cuts are obtained with Alu I (Bruce et al. 1999). Easily differentiable restriction patterns were established based on the variety of restriction fragment sizes produced with each enzyme, called PA for Alu I and PH for Hha I. The patterns were only based on samples presenting simple infections.

\section{RESULTS}

Size polymorphism in the Pvmsp $3 \alpha$ gene - Fiftyfive of the 56 samples were successfully amplified, and, based on the length variants of the PCR products, three allele sizes were detected corresponding to the types reported by Bruce et al. (1999) as being types A $(1,900$ bp), B (1,500 bp) and C (1,100 bp). Type A was the most predominant with a frequency of $96.4 \%$ (53/55), while types $\mathrm{B}$ and $\mathrm{C}$ accounted for a very low percentage, $1.8 \%$ $(1 / 55)$ and 3.6\% (2/55), respectively.

Simple or mixed infection - To establish if an infection was mixed, we used two different criteria: (i) PCR, when more than one band was obtained from the sample and the sizes coincided with some of the reported types, or (ii) RFLP, when the sum of the fragments produced in enzymatic restriction with $A l u$ I or Hha I was greater than the PCR product size. In the case of PCR, only one sample had a mixed infection, presenting types $\mathrm{A}$ and $\mathrm{C}$ simultaneously; $98.2 \%(54 / 55)$ of the samples presented simple infections when taking just the PCR results into account. Enzymatic restriction results of the 55 samples analyzed revealed that 35 (63.6\%) corresponded to simple infections and $20(36.4 \%)$ to mixed infections. This shows that, in areas where a particular type of gene predominates, PCR results are not enough for making a correct classification of the infection type present in the sample.

$R F L P$ - Seven easily distinguishable restriction patterns were detected after the PCR products were digested with the Alu I enzyme (Fig. 1), with fragments between $40-750$ bp being observed. Fragments having

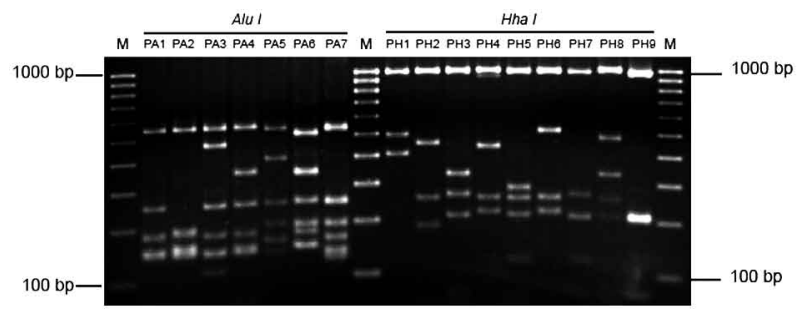

Fig. 1: restriction patterns observed for the Plasmodium vivax msp $3 \alpha$ gene in the municipality of Tierralta, Colombia. Patterns with Alu I: the PA1 pattern coincided with the pattern of the Salvador I control strain. The differences found in the other patterns can be summarised as follows: the PA2 pattern did not present the 260 bp band, each PA3, PA4 and PA5 pattern presented its specific band ( $472 \mathrm{bp}, 360 \mathrm{bp}$ and $413 \mathrm{bp}$ respectively) and, differently to the others, the band having the greatest weight in the PA6 pattern was observed to be slightly smaller (527 bp). The PA7 pattern was very similar to the PA1 pattern; however, it is worth mentioning that this pattern corresponded to a sample having the B type gene whilst PA1 corresponded to a sample having the type A gene. Patterns with $H h a$ I: the 1,000 bp band was slightly polymorphic but was not taken into account for the analysis. The PH3 pattern predominated $(31.4 \%$ of samples having simple infections, 11/35). The PH9 pattern corresponded to the only sample presenting the type B gene.

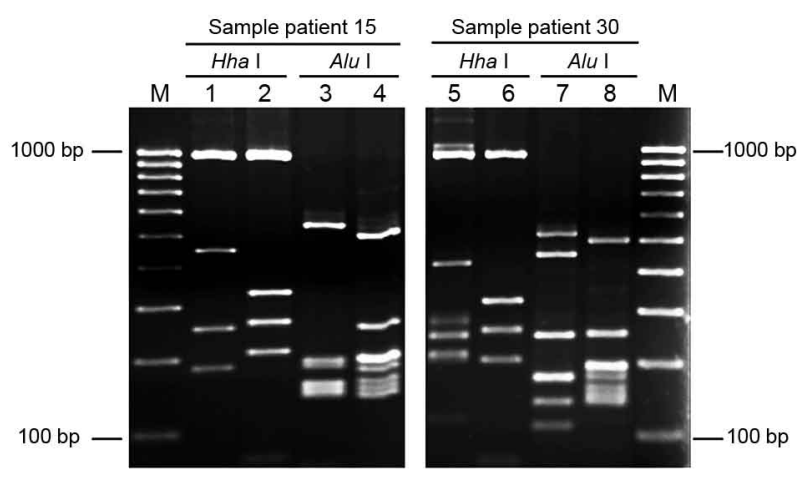

Fig. 2: restriction patterns for the paired samples taken from patients 15 and 30 using the Hha I or Alu I enzymes. M: 100 bp marker; Lanes 1-4: samples from patient 15; Lanes 5-8: samples from patient 30. Lane 1: day 0, with Hha I; Lane 2: day 42, with $H h a$ I; Lane 3: day 0, with Alu I; lane 4: day 42, with Alu I; Lane 5: day 0, with Hha I; Lane 6: day 51, with Hha I; Lane 7: day 0, with Alu I; Lane 8: day 51, with Alu.

less than $250 \mathrm{bp}$ of molecular size were not included for differentiating restriction patterns since our electrophoresis conditions did not allow these bands to be clearly resolved. The PA1 pattern predominated, being observed in $37.1 \%$ of the samples having simple infections (13/35). Fragments between 50-1,000 bp were observed after PCR product digestion with the Hha I enzyme, and all of the bands were used for establishing the patterns. Nine different restriction patterns were found (Fig. 1). The importance of using at least two restriction enzymes should be stressed because, in some cases, samples that had initially been classified as being simple infections based on the results of digestion with one of the enzymes were subsequently identified as mixed infections with the 2 nd enzyme. Each sample with a simple infection 
TABLE

Frequencies of restriction patterns of the Plasmodium vivax msp $3 \alpha$ gene found in Colombian samples

\begin{tabular}{lccccc}
\hline Pattern & $\begin{array}{c}\text { Samples } \\
\mathrm{n}(\%)\end{array}$ & Pattern & $\begin{array}{c}\text { Samples } \\
\mathrm{n}(\%)\end{array}$ & Pattern & $\begin{array}{c}\text { Samples } \\
\mathrm{n}(\%)\end{array}$ \\
\hline PA1 & $13(37.1)$ & PH1 & $2(5.7)$ & PA1 PH1 & $2(5.7)$ \\
PA2 & $3(8.6)$ & PH2 & $3(8.6)$ & PA1 PH3 & $7(20)$ \\
PA3 & $9(25.7)$ & PH3 & $11(31.4)$ & PA1 PH5 & $1(2.9)$ \\
PA4 & $4(11.4)$ & PH4 & $5(14.3)$ & PA1 PH6 & $2(5.7)$ \\
PA5 & $3(8.6)$ & PH5 & $5(14.3)$ & PA1 PH8 & $1(2.9)$ \\
PA6 & $2(5.7)$ & PH6 & $4(11.4)$ & PA2 PH2 & $3(8.6)$ \\
PA7 & $1(2.9)$ & PH7 & $3(8.6)$ & PA3 PH4 & $5(14.3)$ \\
& & PH8 & $1(2.9)$ & PA3 PH6 & $4(11.4)$ \\
& & PH9 & $1(2.9)$ & PA4 PH5 & $4(11.4)$ \\
& & & & PA5 PH7 & $3(8.6)$ \\
& & & & PA6 PH3 & $2(5.7)$ \\
& & & & PA7 PH9 & $1(2.8)$ \\
\hline Total & 35 & & 35 & & 35 \\
\hline
\end{tabular}

was analyzed by putting the patterns of both enzymes together, thereby finding 12 easily differentiable variants. The frequencies for all of the patterns are in Table.

Genotyping of paired samples - The two paired samples from the two patients presenting a new episode of malaria were genotyped to establish the parasite's allelic pattern in both episodes. An amplification product corresponding to the type A gene was obtained in both patients by PCR, but, when analysis was performed using RFLP, it was found that restriction patterns were different for both enzymes (Fig. 2). The 1st sample from patient 15 had PA2 and $\mathrm{PH} 2$ patterns, while the 2 nd sample presented PA1 and $\mathrm{PH} 3$ patterns. Likewise, the 1st sample from patient 30 presented PA3 and PH4 patterns, and the 2nd sample presented PA1 and PH3 patterns, proving that different parasites were being dealt with in each malarial episode.

\section{DISCUSSION}

The results of this work indicate that the $P$. vivax population is highly diverse; 12 different patterns were found in the Pvmsp $3 \alpha$ gene in the 35 samples analyzed. Six of the restriction patterns identified with the Hha I enzyme were similar to those found in Thailand (Cui et al. 2003b) and Iran (Zakeri et al. 2006), and at least three patterns were comparable to those reported in Papua New Guinea (Bruce et al. 1999), suggesting that some variants of $P$. vivax have a global distribution. Nevertheless, a few of our patterns did not match with any of the patterns of these three works. Further studies are required and should include a larger number of samples from places in different malaria-endemic areas in Colombia in order to establish if the genotypes found in Tierralta circulate throughout the whole country or if there are regional differences. It must be taken into account that the transmission intensity of malaria in this locality is high. It is important to bear in mind that each region has different eco-epidemiological characteristics and levels of transmission, and that the distribution of
Plasmodium species also varies between them. The high degree of variation at the genetic level found in $P$. vivax agreed with that observed in other Colombian studies in which micro-satellites have been used (Imwong et al. 2007a). Such levels of polymorphism could be supported by the fact that the msp $3 \alpha$-encoding gene has antigenic properties, meaning that a specific allele is not selected but instead this diversity is maintained by positive selection. However, there could be other reasons, including some of the parasite's biological properties, such as their ability to relapse, interactions with co-circulating P. falciparum populations or the migration of infected people from one region to another. This last possibility deserves special attention because, during the last few years, part of the rural Colombian population has been subjected to intense and continuous displacement.

The percentage of mixed infections found in this study was high $(36.4 \%)$, which is in agreement with the $40 \%$ reported by Imwong et al. (2007a) in Colombian samples. This work showed that the $P$. vivax populations from Tierralta are genetically diverse, and these results contrast strongly with those from studies of $P$. falciparum diversity, where very genetically homogenous populations have been found (Guerra et al. 2006).

The results of the enzymatic restriction with the paired samples showed that the patterns from both days were completely different, implying that the parasites were different clones on both occasions. This led to us suggest that these patients, who responded suitably to the treatment, suffered re-infection since no similar patterns or shared bands were found in the paired samples. On the other hand, these patients stayed in the same endemic zone all the time, making it possible for them to acquire a new infection. However, these results must be interpreted with caution since they could also have presented a relapse caused by activation of heterologous hypnozoites that persisted in the liver from the 1st infection (Imwong et al. 2007b). Also, it must be considered that the relapses produced by $P$. vivax from tropical regions are characterised by short latent periods (5-10 weeks). It cannot be categorically stated that a new infection is being dealt with since no methods have been developed to date that allow differentiation to be made without ambiguity between reinfection or relapse.

It has been shown that the msp $3 \alpha$ gene is a good molecular marker for analysing the genetic diversity of $P$. vivax populations in Colombia. In addition, the combined PCR-RFLP protocol offers several advantages as it is a simple method allowing great genetic variability to be observed as well as the analysis of a large amount of samples obtained in epidemiological studies. However, it is worth mentioning that this gene is under strong diversifying selection and in future studies must be used in parallel with neutral markers such as microsatellite DNA markers.

\section{ACKNOWLEDGEMENTS}

To Dr. S Herrera, Universidad del Valle, M Peña, and all the staff from the Municipal Secretariat of Health, Tierralta, and E Diaz for their valuable collaboration; to E Hernández, D Vargas and J Sierra, for their work reading microscope slides for malaria diagnosis, and to J.Garry, for the translation of this paper. 


\section{REFERENCES}

Bruce MC, Galinski MR, Barnwell JW, Snounou G, Day KP 1999. Polymorphism at the merozoite surface protein- $3 \alpha$ locus of Plasmodium vivax: Global and local diversity. Am J Trop Med Hyg 61: 518-525.

Cui L, Escalante AA, Imwong M, Snounou G 2003a. The genetic diversity of Plasmodium vivax populations. Trends Parasitol 19: 220-226.

Cui L, Mascorro CN, Fan Q F, Rzomp KA, Khuntirat B, Zhou G, Chen H, Yan G, Sattabongkot J 2003b. Genetic diversity and multiple infections of Plasmodium vivax malaria in Western Thailand. Am J Trop Med Hyg 68: 613-619.

de Santana Filho FS, Arcanjo AR, Chehuan YM, Costa MR, Martinez-Espinosa FE, Vieira JL, Barbosa MG, Alecrim WD, Alecrim MG 2007. Chloroquine-resistant Plasmodium vivax. Brazilian Amazon. Emerg Infect Dis 13: 1125-1126.

de Souza-Neiras WC, de Melo LM, Machado RL 2007. The genetic diversity of Plasmodium vivax - A review. Mem Inst Oswaldo Cruz 102: 245-254.

Feng X, Carlton JM, Joy DA, Mu J, Furuya T, Suh BB, Wang Y, Barnwell JW, Su XZ 2003. Single-nucleotide polymorphisms and genome diversity in Plasmodium vivax. Proc Natl Acad Sci USA 100: 8502-8507.

González JM, Hurtado S, Arévalo-Herrera M, Herrera S 2001. Variants of the Plasmodium vivax circumsporozoite protein (VK210 and VK247) in Colombian isolates. Mem Inst Oswaldo Cruz 96: 709-712.

Guerra AP, Knudson A, Nicholls RS, Galindo JA, Ravid Z, Rahirant S, Duarte N, Chaparro-Olaya J, Wasserman M 2006. Genotipificación de los genes msp1 (bloque 2) y dhfr (codón108) de Plasmodium falciparum en muestras de campo recolectadas en cuatro localidades endémicas de Colombia. Biomédica 26: 101-112.

Gutierrez A, Vicini J, Patarroyo ME, Murillo LA, Patarroyo MA 2000. Plasmodium vivax: polymorphism in the merozoite surface protein 1 gene from wild Colombian isolates. Exp Parasitol 95: 215-219.
Imwong M, Nair S, Pukrittayakamee S, Sudimack D, Williams JT, Mayxay M, Newton PN, Kim JR, Nandy A, Osorio L, Carlton JM, White NJ, Day NP, Anderson TJ 2007a. Contrasting genetic structure in Plasmodium vivax populations from Asia and South America. Int J Parasitol 37: 1013-1022.

Imwong M, Sudimack D, Pukrittayakamee S, Osorio L, Carlton JM, Day NP, White NJ, Anderson TJ 2006. Microsatellite variation, repeat array length, and population history of Plasmodium vivax. Mol Biol Evol 23: 1016-1018.

Imwong M, Snounou G, Pukrittayakamee S, Tanomsing N, Kim JR, Nandy A, Guthmann JP, Nosten F, Carlton J, Looareesuwan S, Nair S, Sudimack D, Day NP, Anderson TJ, White NJ 2007b. Relapses of Plasmodium vivax infection usually result from activation of heterologous hypnozoites. J Infect Dis 195: 927-933.

INS - Instituto Nacional de Salud 2005. Informe Vigilancia Epidemiológica de las Enfermedades Transmitidas por Vectores, INS-Subdirección de Vigilancia y Control en Salud Pública, Bogotá, Colombia. Available from: http://www.ins.gov.co/pdf/vcsp/ Tablas/2005/2005_semana_52.pdf.

Maestre A, Sunil S, Ahmad G, Mohmmed A, Echeverri M, Corredor M, Blair S, Chauhan VS, Malhotra P 2004. Inter-allelic recombination in the Plasmodium vivax merozoite surface protein 1 gene among Indian and Colombian isolates. Malar J 3: 4.

Mancilla LI, Levitus G, Kirchgatter K, Mertens F, Herrera S, Del Portillo H 1994. Plasmodium vivax: dimorphic DNA secuences from the $M S P$ - 1 gene code for regions that are immunogenic in natural infections. Exp Parasitol 79: 148-158.

Pérez MA, Cortés LJ, Guerra AP, Knudson A, Usta C, Nicholls RS 2008. Eficacia de la combinación amodiaquina+sulfadoxina-pirimetamina y de la cloroquina para el tratamiento de la malaria en Córdoba, Colombia, 2006. Biomédica 28: 148-159.

Rodríguez-Morales A, Benítez J, Arria M 2008. Malaria mortality in Venezuela: focus on deaths due to Plasmodium vivax in children. J Trop Pediatr 54: 94-101.

Zakeri S, Barjesteh H, Djadid ND 2006. Merozoite surface protein-3 $\alpha$ is a reliable marker for population genetic analysis of Plasmodium vivax. Malar J 5: 53. 